\title{
Taking Ontology Seriously in Political Science and Political Theory: A Reply to Mayhew*
}

The June 2000 issue of $P S$ featured a symposium on "Political Science and Political Philosophy," that included three papers first given as part of a political science department workshop at Yale. Let me start by expressing my admiration of that department for encouraging such conversation.

I want to engage the thoughtful paper by David Mayhew, "Political Science and Political Philosophy: Ontological Not Normative." He suggested that it does not make good sense to think of the division of labor between political science and political theory as involving inquiry into, respectively, "is" and "ought." This allocation of tasks tends to "marginalize or trivialize" political theory in a way that is unwarranted, because it fails to attend to the important role ontological reflection plays in how scholars conceptualize politics. Rather than understanding political theory to be simply clarifying "ought" questions, political scientists should see it rather "as a source of ontological illumination-that is, as a window to the nature of political reality." The history of political theory, from Plato to the present, constitutes a repository of different ways of comprehending politics. Mayhew sketched four such accounts of what constitutes political reality: "patterns of conflict or coalition," "participation," "steering," and "unfolding/ structures."

Now, I could quibble about this particular list, but the more important issue is really the question of what exactly is implied by Mayhew's general emphasis on ontology. ' Broadly speaking, I agree with that stance. My main interest here is to probe two issues that become pressing once ontological matters are brought into the foreground. The first concerns ontological pluralism; the second, the relation of the ontological to the normative.

\section{Issue 1}

When one speaks of illuminating political reality, does that imply that there is ultimately one correct ontological account, even if no one has yet found it? For Mayhew, scholars "keep resorting" to political theory because they have no "clear, singular answer" at this point as to what political reality is. Moreover, they are "probably fated to continue in [this] condition of ontological pluralism." I assume Mayhew is arguing that because political scientists have not been able to agree up to this point on one, true ontological account of political reality, it is therefore reasonable not to expect ontological pluralism to disappear.

In the way I have just stated this argument, it may seem straightforward. But that is not the case. There are at least two ways of understanding what one has learned from this long history of nonagreement. One is to think that comprehending the true nature of political reality is immensely diffcult; therefore, there is no reason to expect that the task of finding the one true account will be completed soon. In effect, all "window[s] to the nature of political reality" have had partially distorted glass, and political scientists are nowhere near knowing how to create the undistorted glass they need to fulfill their task. A different way of understanding what one has learned produces the realization that political scientists have been searching for something that does not exist; namely, one true ontological account. Part of their mistake would lie in how they have been imagining the function of ontologies: as if they were "windows." Recognition of this mistake brings one to conclude that the reason no one has been able to capture political reality through one all encompassing ontological account is because none provides what are simply clear or distorted views of their object; rather they partially constitute or construct it. Hence, the very idea of one clear picture of political reality is confused.

I would suggest that the second lesson is the more defensible one to have learned. But it is important to be clear as to the exact character of this lesson, because it can be misinterpreted as some sort of denial of reality in the name of "constructivism." The criticism often offered at this point is that when one contends that reality is constituted by interpretations (and I take ontologies to be simply our deepest level of interpretation), then one is committed to denying that there is a reality beyond language. Accordingly, realists in international relations like to poke fun at their constructivist opponents by contending that, regardless of the given interpretive or discursive context, a well-aimed bullet fired by one actor is sure to injure the other. This proverbial bullet may always strike home, but the same is not true for the conceptual point it is supposed to carry with it. Perhaps there are some who believe, literally, that "there is no-thing outside the text" (the interpretation, the discourse, etc.), but I have never met any political theorists of this persuasion The key insight of constructivism is that reality is, well, brute--as in rough and uncommunicative. An appeal to the reality that lead rips flesh does not, by itself, tell anyone much about political life until after it is embedded in ontological accounts of human being, conflict, and so on (see Campbell forthcoming; White 2000).

If this constructivist interpretation of Mayhews appeal to ontological pluralism is correct, then scholars have good reasons for considering such pluralism to be inherent in political inquiry. This kind of strong endorsement of pluralism makes some political scientists nervous because it seems 
incompatible with any idea of progress in political inquiry. But this is not so. It may be incompatible with some ideas of progress, but not all. Consider here Mayhew's concluding remark that different ontological accounts within the repertoire of political theory "can be dusted off for use when the profession's ontological tastes shift, as they sometimes do." Presumably, these "tastes" of the profession reflect changing perceptions in society itself as to what are its most salient problems at a particular moment in history. Seen from this broadly pragmatist perspective, political science is progressive insofar as it actively supports a diverse repertoire of ontological accounts (and research traditions in which they are embedded) that can be drawn upon when a society's perceptions shift. John Dryzek has laid out a notion of progress along these lines as an enhanced capacity to "cope with contingency" (Dryzek $1990,190-221$ ).

\section{Issue 2}

Mayhew's emphasis on ontology is couched in such a way that it raises a question as to the relation between ontological accounts and normative claims. As I read him, he argued that a normative judgment cannot be logically deduced from an ontological account of political reality. That seems generally correct, as political theorists such as Charles Taylor (1995, 181 83) have noted. But, to affirm this is not to deny that ontological accounts, in which political scientists' identities and behavior are embedded, are deeply entangled with nonnative judgments. In the way they focus scholars' attention cognitively and figure their sensibility, ontological frames implicitly provide political scientists with normative bearing toward the world. All of these interconnections are part of what political theorists properly investigate

If one focuses, however, not on a single ontological account, but rather on the principle of ontological pluralism and the associated, pragmatist conception of progress, one discovers something different about necessary normative commitments on the part of political scientists. The criterion of progress requires the discipline to respond to what are taken to be society's problems. But, of course, problems do not fall like apples from a tree into the lap of an entity called "society." There is always the question of how a problem is defined and exactly who in society does the defining. What is crucial here is to understand that this normative issue now must be seen as a matter on which political scientists will always have to take a position. Their scientific activity implies a moral-political stance. With their decisions about the best cognitive resources for responding to society's problems, political scientists are simultaneously and necessarily endorsing some normative answer to the "how" and "who" of problem constitution, A political scientist may decide simply to accept the answer provided by the political status quo in a given society, or she may decide to affirm some critical perspective and imagine her work as helping to bring into better focus the kinds of theoretical initiatives and empirical investigations that would be more appropriate to that different perspective on problem constitution. In short, a political scientist is not constrained by the implications of her cognitive activity to choose one moral-political alternative; but she is constrained to choose, or have chosen for her, some alternative. ${ }^{2}$

Stephen K. White Virginia Tech

\section{Notes}

* The author would like to thank John Dryzek and J. Donald Moon for their comments.

1. Recourse to the question of ontology in political science and political theory first made its appearance in a set of related methodological essays in the late 1970s and 1980s. Crucial in this regard are Moon (1975), Fay and Moon (1977), and Ball (1987). The first two essays employ the Lakatosian language of "research programs"; the basic conceptualization of entities within a program was called the "hard core." Ball's essay, under the influence of Larry Laudan's work, explicitly refers to the "ontology" of a "research tradition."

2. I differ a bit from Dryzek on this point. He argues that the cognitive commitments of political scientist entail the affirmation of a critical, democratic perspective on the matter of how social problems are to be constituted (1990, 211-12, 219)

\section{References}

Ball, Terence. 1987. "Is There Progress in Political Science?" In Idioms of Inquiry: Critique and Renewal in Political Science, ed. Terence Ball. New York: State University of New York Press.

Campbell, David. Forthcoming. "International Engagements: The Politics of North American International Relations Theory." Political Theory.

Dryzek, John. 1990. Discursive Democracy: Politics. Policy and Political Science. Cambridge: Cambridge University Press.

Fay, Brian, and J. Donald Moon. 1977. "What Would an Adequate Philosophy of Social Science Look Like?" Philosophy of the Social Sciences 7(3): 209-27.

Moon, J. Donald. 1975. "The Logic of Political Inquiry: A Synthesis of Opposed Perspectives." In Handbook of Political Science, vol. 1, ed. Fred Greenstein and Nelson Polsby. Reading, MA: AddisonWesley.

Taylor, Charles. 1995. Philosophical Arguments. Cambridge, MA: Harvard University Press.

White, Stephen K. 2000. Sustaining Affirmation: The Strengths of Weak Ontology in Contemporary Political Theory. Princeton: Princeton University Press.

\section{Lawsuit Filed to Intimidate Researchers}

I am writing to request the support of APSA members in my defense against a lawsuit that has been filed against me by Laredo National Bancshares, Inc., Laredo National Bank (LNB), and Gary G. Jacobs, president and CEO of those organizations. There are major First Amendment issues involved in the case that should be of interest to Association members, most notably the threat to academic freedom.

The lawsuit stems from alleged actions I committed while I was a research professor on U.S.-Latin American security issues at the U.S. Army War College (USAWC). The charges are multiple and involve accusations that I infiltrated a U.S. intelligence agency-the National Drug Intelligence Center (NDIC)- 
for the purpose of corrupting its investigations of narcotrafficking and related criminal activities. Specifically, I am accused of having given NDIC false and defamatory information on Mexico's powerful Hank family and its businesses and associates (which include LNB and Gary Jacobs) as part of an 800-page report on the Hanks and a 19-page executive summary of that report which was leaked to various reporters. Allegedly, I conspired in these activities with a number of unidentified individuals for my own financial or other gain.

At the time of these alleged events (1998-99), I was a research professor for the USAWC's Strategic Studies Institute (SSI) engaged in work on a study titled

"Narcopolitics in Mexico." During the course of this activity, I talked with people within U.S. government agencies and outside them, including academics and journalists, for purposes of gathering information for my report. These contacts were within the scope of my legitimate academic research activities, and did not in any way constitute an attempt to "corrupt" an official investigation or defame the plaintiffs. Subsequently, in August 1999, I left SSI to become a professor and chair of the political science department at Cleveland State University. The lawsuit was filed in August 2000.
This lawsuit raises a number of alarming issues, but the one of most fundamental concern to APSA is the threat being posed to the First Amendment rights of free speech and free press--in particular, the right of private scholars, as well as government researchers and journalists, to research and write about organized crime and other threats to national security. I am not the only target. The lawsuit lists unidentified John Does as co-conspirators, and several U.S. government employees are identified as having given me misinformation, apparently as part of this alleged plot. During preliminary efforts to settle the case out of court, the plaintiffs' attorneys have suggested I allow my phone to be tapped and that I wear a microphone in an effort to flush out other alleged co-conspirators. I have declined their offer. Indeed, I could not comply if I wanted to since, to the best of my knowledge, there is no conspiracy.

Nor are U.S. Government researchers the only targets. A separate lawsuit had previously been filed against a private researcher, Christopher Whalen, for allegedly giving damaging information on LNB to the Federal Reserve. A number of other individuals and periodicals, including $E l$ Andar and El Financiero, have been threatened with suits. The object, clearly, is to intimidate government researchers, scholars, and journal- ists in order to deter them from investigating the Hanks and their associates. Whalen, myself, and probably others are to be made object lessons to those who might be tempted to write or provide information on the Hanks' business dealings. If the Hanks can get away with this, other suspect groups, whether criminal or political, will be encouraged to adopt similar tactics. The result will be a serious blow to academic freedom and free speech.

In response to this harassment, some of my colleagues are investigating how to set up a Legal Defense Fund on my behalf. I have only modest financial means-certainly not enough to defend myself against plaintiffs who have, almost literally, unlimited resources. We are asking a number of professional organizations to cosponsor the fund. But all this takes time. Meanwhile, the legal battle has begun, and my costs are mounting.

Given the above, I would simply ask colleagues who would like to support my defense effort to send contributions payable to the "Donald Schulz Legal Defense Fund" to Philip Althouse, Attorney at Law, 2012 W 25th St., Ste. 715, Cleveland, $\mathrm{OH} 44113$.

To those who care to contribute, I thank you from the bottom of my heart.

Donald Schultz Cleveland State University

\section{Some Further Sources on Nonviolence as Strategy and Philosophy}

In addition to the articles published in the symposium titled "A Force More Powerful," may I suggest immodestly that my article, "On Civil Disobedience in Recent American Democratic Thought" (APSR, March 1970) may still have some bearing.

As to the Gandhian traditions, 10 papers comprise The Meanings of Gandhi (University Press of Hawaii, 1971), which I edited following an East-West Center symposium. Contributors to that volume include B.R. Nanda, Ainslie T. Embree, N.T. Bose, and Donald E. Smith. And, in my view, the leading book on Gandhi's ideas remains Raghavan Iyer's The Moral and Political Thought of Mahatma Gandhi (Oxford University Press, 1973).

The application of nonviolence to political conditions is evaluated in William Stuart Nelson 's "Gandhian Values and the American Civil Rights Movement" in The Meanings of Gandhi. I tried to do the same in another context in my "Civil Protest in Northern Ireland" (Journal of Peace Research, 1972). Intrepid partisans of nonviolent action like Gene Sharp and Howard Zinn never explained why this behavior is so difficult to sustain before it passes into violence or simply stops. Doubtless, defenders will cite the Polish example. The ambivalent quality of nonviolent protest respecting the prospect of violence is clear in the Irish and South African cases (the latter is recognized by Gay W. Seidman in her $P S$ piece).

In any event, "A Force More Powerful" is a welcome recalling of the nonviolent political tradition. Peter Ackerman and Jack DuVall are to be congratulated for their enterprise.

Paul F. Power University of Cincinnati 
The growing number of articles on service learning, field courses, advocacy learning, and theories of democratic education in $P S$ is extremely encouraging. So is the profession's growing interest in and commitment to these related approaches to civic education, including its new web sites (www.apsanet.org/service; www.apsanet.org/teaching/ CENnet). Yet, the discussion needs both a better focus and firmer infrastructure to ensure its lasting benefits.

\section{Dimensions}

In many respects, an overall analysis of political science education at the university level, in terms of how well it promotes the development of specific skills and perspectives, would help curriculum reformers focus their debates exactly on where the weaknesses are and how all the potential reforms relate to each other. At the same time, a longer historical study that reveals the origins of the different dimensions of civic education could prevent reformers continually reinventing the wheel.

Political science programs are evaluated often, but little effort has been made to develop analyses and evaluation criteria that would, for example, convey to students and the public exactly how particular curricula compare in terms of their likelihood for developing laboratory skills, abilities to advocate causes effectively, model building, and democratization of the classroom. I suggested developing such measures in this very space more than four years ago ("Measuring the Best," PS, September 1996). I have now developed such indicators and criteria for universities throughout the world in projects to transform university programs in transitioning and developing countries. The critiques and ideas presented in $P S$, however, remain ad hoc and make it difficult to advance change and draw conclusions from the debate.

In "The Impact of Service Learning on Democratic and Civic
Values," Susan Hunter and Richard Brisbin Jr. (PS, September 2000) use some (but only a small part of the long list) of the criteria that Xavier Briggs, Arturo Cherbowski, I, and several other colleagues developed in Escape from the Ivory Tower: Student Adventures in Democratic Experiential Education (1996) to test the benefits of service learning. However, Hunter and Brisbin were actually testing it only on one of the many models of service learning, not on any like the one described by Tony Robinson in "Service Learning as Justice Advocacy: Can Political Scientists Do Politics?" (PS, September 2000). Nor did Hunter and Brisbin conduct their study using a control group of students in a standard political science class. Robinson is, in fact, critical of the service learning internship model that Hunter and Brisbin have implemented and then tested, finding many of the same weaknesses that authors he cites and other authors we cited found.

Certainly, the approach that we developed to supplementing and reshaping the curriculum, especially one program in "national development planning" that we tested with Harvard and Brown University students in Ecuador in 1988, was a quite different interpretation of service and advocacy. Students working on the Ecuador project conducted research throughout Ecuador, tested theories, wrote a development plan in Spanish in three months, and arranged an appointment to discuss their ideas with the country's president followed by a nationally televised press conference. The student team and I published our work in $A$ Model Development Plan (Greenwood, 1995).

Academic publishing, appearances at national press conferences, and lobbying presidents of foreign countries in a second language certainly added to the repertoire of skills that students learned and gave them a deep appreciation of concepts like "service," "advocacy," and "field work." This approach to learning should certainly be treated and evaluated separately from the model of working in soup kitchens or nongovernmental organizations. Despite this, no discussion of this approach to service learning or advocacy has appeared in $P S$, even though the outputs and skills that students develop are quite clear and easy to measure against those students gain in traditional classes.

The model that we implemented at Stanford in 1985, at the University of California, Berkeley in 1987, and elsewhere since then, well before there were opportunities to present such case studies in $P S$, actually bridges and incorporates service, field and laboratory methods for testing theory and developing analytical skills, advocacy, and democratization of the classroom itself. We actually developed this approach in response to what we recognized were weaknesses or failures of the internship model and the simulations model, and we set forth a series of indicators and several different measures for testing skill attainment, along with several different syllabi. Our hope was that others would test the different dimensions, compare all of the different models and build on our set of indicators. That has yet to happen. Many of the reports of civic education remain incidental and unconnected case studies, without control groups or descriptions of where these innovations fit into an entire curriculum and strategy of learning.

\section{Structures}

If the discussion of effective civic education is really to progress constructively, instructors will need to begin to develop inclusive structures for promoting the kind of analysis of teaching they have become accustomed to doing in their scholarly work.

One of the major problems facing civic educators is that they simply do not have a place to review the few new books that are being published in the field of political science pedagogy. While PS has 
opened space for case studies, neither $A P S R$ nor $P S$ have yet set aside space for reviews of books that present entire sets of case studies or curricular designs and the theory behind them. Why not? Could $P S$ 's editors make a commitment to print such reviews?

The absence of book reviews has actually begun to suffocate what should be a growing field. Jossey Bass, which published Escape from the Ivory Tower as well as Barbara Jacoby's book on internships and several earlier works in the field, simply believes that the demand is not enough to support publishing works on new educational approaches and cite the lack of reviews as an important cause of poor sales. The minimum sales they are now seeking are 5,000 copies per book. Both Professor Jacoby's book and ours sold more than 1,000 copies, which is already three times the average for most academic books. Certainly, this new threshold is one that those with innovative ideas will never be able to reach. Jossey Bass' closing of their doors leaves publishing crtical evaluations of civic education open only to those who print work through associations or institutes. So, what have we done to ourselves? Can we create the space on our own to keep this discussion going?
Another way to move the discussion of civic education towards more critical analysis would be to open up the pages of $P S$ to a forum of practitioners of different approaches to describe their philosophies for simulations, advocacy classes, democratizing the classroom, encouraging service internships, and conducting laboratory field work. The forum could also include traditionalists and representatives of fields other than political science, beginning what could be a provocative interaction that would reinvigorate teaching across political science.

David Lempert

Unseen America Projects, Inc.

\section{Attention to Process Blinds Political Scientists to Real Causes of World Problems}

Many years ago I became a dropout from the American Political Science Association. Throughout the early years of my career, I faithfully attended meetings and participated in the organization's activities. As my interests shifted from narrow concerns over political socialization to larger questions concerning why people throughout time have been so willing to kill each other, and specifically so willing to commit acts of genocide, I found the Association to be almost completely irrelevant to those concerns. My conclusions were reinforced recently as I searched, in vain, through the program for the 2000 APSA Annual Meeting for some indication that the organization was interested in the continuing violation of human rights and commission of genocide around the globe. Even I, however, was surprised when, as part of my search, I came upon a statement so outrageous and misinformed that I could scarcely believe I had seen it in print. Recovering, I realized that it was simply one more indication of the banality of the organization's concerns.

The statement appears in an article called "Linking Public Administration to Comparative Politics," which appears in the
September 2000 issue of PS. As an illustration, it merits quotation.

Sierra Leone, which once produced $\$ 500$ million worth of diamonds a year, currently exports less than $\$ 30$ million, according to records kept in Antwerp .... A brutal civil war that has lasted since the early $1990 \mathrm{~s}$ partly accounts for this, but secondary corruption (when greed is uncontrolled by governance) remains the underlying cause. (585)

The author proceeds to note that "bribery and extortion" are considered "standard operating procedure" in Sierra Leone and that

While the poor quality of political software in Sierra Leone might be blamed on the miserably paid and undisciplined civil servants, it is actually those earning high salaries, primarily government ministers and senior civil servants, [who] have indulged in more fraud than junior workers or private citizens. (585)

So, for the modern political scientist, the failure of Sierra Leone to export diamonds is due to corruption and to the "poor quality of political software," whatever that might entail.

Sierra Leone has been called, in the pages of The New York Review' of Books, "The-Worst Place on Earth" (Traub 2000, 61). It is a place where a brutal war between government and rebels has been ongoing since 1991. The struggle has been referred to as a "horrifyingly obscure war" because it is "not a struggle between political parties or ethnic groups," nor is it a "fight between government and rebels" ("The Darkest Corner" 1999).

The rebels call themselves the Revolutionary United Front (RUF), and it is not clear precisely what it is they are for or against. The rebel movement was founded by Foday Sankoh, who has been in prison in Freetown. They are the ones who live off and control the diamond mines and terrorize the population by "chopping off the arms and hands of men, women and children" (Roth 2000).

Interestingly, attempts to bring peace to Sierra Leone have failed. Through a series of miscalculations on the part of the United Nations and the United States, including the RUF taking several hundred UN troops hostage, the situation has simply become intolerable.

In short, diamonds have not declined as an export because of "secondary corruption" and "political software," but because the diamonds are being used to finance the activities of a brutal group attempting to seize control of the 
government by committing the most unspeakable of human rights violations.

It is very clear that peace will not come to Sierra Leone until the United Nations is prepared to undertake another peacekeeping operation, fully funded and fully staffed with heavily armed personnel. This is, in fact, the lesson drawn from the recent millennium conference held at the United Nations, where it was concluded that peacekeeping operations must be placed on a more secure financial and military basis if they are to be successful in cases such as that in Sierra Leone.

As the United Nations realized that merely talking about keeping the peace would not accomplish that fact, it is time political scientists understood that their fixation on formal processes and abstract theories blinds them to the reality of cruelty and death as important implements of politics.

Herbert Hirsch, Virginia Commonwealth University

\section{References}

"The Darkest Corner of Africa." 1999. The Economist, January 9, 441-42.

Roth, Kenneth. 2000. "International Injustice: The Tragedy of Sierra Leone," The Wall Street Journal Europe, August 2, A6.

Traub, James. 2000. "Sierra Leone: The Worst Place on Earth." The New York Review of Books, June 29, 61-66.

Werlin, Herbert H. 2000. "Linking Public Administration to Comparative Politics." PS: Political Science and Politics 33(September): 581-88

\section{make \\ APSANet}

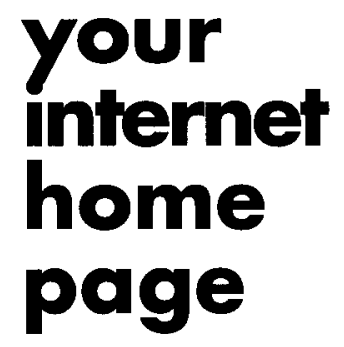

FAST

AND

EASY!

for Microsoft Explorer

from the menu bar select Tools

Under Tools select Internet Options

Under the tab marked General you can change which page to use for your home page.

Enter http://www.apsanet.org Click OK.

\section{for Netscape Navigator or Communicator \\ from the menu bar select Edit \\ Under Edit select Preference}

Under the tab marked Navigator you can change which page to use for your home page.

Enter http://www.apsanet.org. Click OK.

\section{APSANet is your source for news and information on APSA and the profession.}

\section{Look for new features such as the online directory of Depart- ment chairs; Service Learning, and a Guide for Graduate Students.}

www.apsanet.org 